\title{
Cantoria de Pé de Parede: a atualização da cantoria nordestina em Brasília
}

\author{
Patrícia Silva Osório
}

resumo Formada por um contingente migratório bastante significativo, notamos na dinâmica urbana da cidade de Brasília a presença de grupos que atualizam manifestações culturais identificadas com seus contextos de origem. Este artigo se ocupa de um desses grupos, os cantadores nordestinos - também conhecidos como repentistas - e de um evento em particular, a Cantoria de Pé de Parede. Analisando o cenário no qual a manifestação é atualizada, as formas poéticas utilizadas, a importância da comensalidade e da idéia de conterrâneo, o objetivo é indicar algumas facetas do modo como esses poetas populares constroem imagens acerca da cantoria, da tradição, de Brasília e do Nordeste.

palavras-chave Cantadores nordestinos. Performance. Tradição. Pertencimento.

Em 1957, quando a nova capital federal era formada pelo Núcleo Bandeirantes e por quatorze acampamentos, foi realizado um primeiro recenseamento que indicava a presença de quatro mil pessoas. $\mathrm{O}$ contingente populacional compunha-se basicamente por trabalhadores não qualificados (cujas procedências eram predominantemente dos Estados de Goiás e Minas Gerais) que vinham trabalhar na construção civil (Sousa 1983: 34). Em 1958, chegaram cerca de cinco mil nordestinos, impulsionados pela grande seca que assolava a regiáo Nordeste. À medida que crescia a população, aumentava o estabelecimento de moradias por invasão. Visando solucionar o problema habitacional da nova capital, surgem as cidades-satélites: em 1958, Taguatinga; em 1959, Sobradinho; em 1960, o Gama (Ribeiro 1982: 119). Em 1971, uma enorme invasão, resultado da destruição de antigos acampamentos era transferida para uma área nas proximidades de Taguatinga. Assim nasce a Ceilândia, conhecida na época pelas siglas CEI, Centro de Erradicação de Invasóes. A CEI se transformou na residência de muitos trabalhadores nordestinos da construçáo civil.

A Ceilândia é o local apontado pelos cantadores como sendo um reduto da cantoria nordestina. Nos finais dos anos sessenta (nas imediaçóes do que hoje é o centro comercial da cidade), os encontros eram feitos no "Bar do Galego”. Após alguns anos de funcionamento, o estabelecimento mudou de proprietário e foi renomeado como o "Bar do Gouveia", mas os encontros não pararam. Atualmente, o ponto de encontro da cantoria nordestina não é nos bares. Foi construído um local específico para a divulgação da cantoria: a Casa do Cantador.

Existem outras Casas do Cantador distribuídas pelo Brasil: Teresina, São José do Egito, Campina Grande, Rio de Janeiro, etc. Da mesma forma que a Casa do Cantador na Ceilândia, elas surgiram com o objetivo de divulgar e manter manifestaçóes culturais ligadas à literatura de cordel e à cantoria nordestina. No entanto, a Casa do Cantador localizada no Distrito Federal apresenta uma particularidade frente às demais: ela é uma instituição pública. Financeiramente, a Casa depende exclusivamente das verbas liberadas pela Secretária de Cultura do Distrito Federal. Se por um lado tal peculiaridade pode implicar no enfretamento de sérios problemas financeiros, vivenciados constantemente pela instituiçáo, por outro 
lado, o fato de ser uma entidade pública significa muito para os cantadores nordestinos em Brasília.

O "mito" de fundação da Casa do Cantador na Ceilândia marca o ano de 1985 como o pontapé inicial para a construção da entidade. Em 1985, aconteceu um Festival de Repente em Brasília, organizado pela Associação de Moradores da Ceilândia. Os cantadores do Nordeste se uniram aos que aqui estavam e foram à residência do então Governador do Distrito Federal, José Aparecido, reivindicar a construção da Casa do Cantador. A idéia era construir um espaço para hospedar cantadores nordestinos de passagem pela cidade, além de ser um local para a realização de grandes festivais e festas ligadas ao cordel e ao repente. No ano de 1986, a Casa do Cantador foi inaugurada pelo Governador e pelo Presidente da República, José Sarney.

As dependências do prédio são amplas. No térreo, anfiteatro, cozinha, dois banheiros, salas para a diretoria, secretaria e biblioteca. No andar superior estáo localizados os quartos e banheiros destinados aos cantadores em trânsito que se hospedam na Casa. O prédio da sede da Casa do Cantador segue os traços de Oscar Niemeyer. Dentre as várias construçóes que levam sua assinatura na capital do país, a Casa do Cantador é o único projeto do arquiteto situado numa cidade-satélite. Conhecida nos noticiários por ser um dos locais mais violentos do Distrito Federal, Ceilândia se orgulha da obra de Niemeyer. Frente aos graves problemas sociais, altos índices de homicídio e roubos, a Casa do Cantador é indicada por muitos ceilandeses como uma das melhores coisas que existem na cidade.

O mito de fundação desse espaço reservado à atualização da cantoria nordestina na capital federal nos coloca diante de algumas questóes. A Casa foi inaugurada pelo Presidente da República. Foi fruto de um projeto assinado pelo mesmo arquiteto que projetou Brasília. Foram os cantadores que, unidos e mobilizados, fizeram a reivindicação ao Governador do Distrito Federal para a construçáo da Casa. A Casa do Cantador é apreendida como uma conquista. A ligação com o poder público assume um lugar importante na forma como os cantadores constroem a instituição. $O$ fato de ser uma instituição pública sugere um reconhecimento formal por parte das instâncias administrativas e políticas. $\mathrm{O}$ relato de fundação da entidade faz parte de todo um contexto, acionado pelos cantadores, que pretende fixar jogos de intençóes. O que denominamos "jogos de intençôes" corresponde às expectativas desses migrantes; aos processos de autoconstrução de si mesmos como nordestinos e como artistas; aos significados de estar em Brasília; às adaptaçóes e inovaçóes que fazem no novo cenário; e ao que selecionam em seu repertório tradicional para a exibição pública. Estas são as questóes que analisaremos nas próximas páginas.

\section{Cantoria de Pé de Parede: o cenário, as formas poéticas e outros ingredien- tes do rito}

Para a adaptação e inserção em novas situaçôes, indivíduos ou grupos muitas vezes recorrem à idéia de tradição cultural. Em contextos migratórios, manifestaçóes tidas como tradicionais convertem-se num estoque de símbolos necessários e eficazes. Lúcia Morales (1993) exemplifica a argumentação ao analisar a Feira de São Cristóvão, localizada no Rio de Janeiro. A concretizaçáo do evento e a história da migraçáo nordestina para o Rio de Janeiro estáo imbricadas. A Feira é vista pela autora como um fator de organização e atualização de uma tradição através da qual identidades são negociadas. É o espaço onde não apenas se comunica o que é ser nordestino, mas principalmente onde a experiência de ser migrante é apropriada para a 
afirmaçáo e legitimação de um lugar dentro da cidade de destino (op. cit.: 64).

A Cantoria de Pé de Parede é o principal evento da Casa do Cantador consagrado à atualização da cantoria nordestina na capital federal. Analisar esse evento nos direciona para a reflexão de temas relativos à reconstrução das idéias do migrante nordestino e da cantoria nordestina, e para as estratégias de inserção dos cantadores e da cantoria nos grandes centros urbanos.

Em todas as sociedades existem eventos que podem ser reconhecidos como rituais por serem considerados especiais (cf. Tambiah 1985; Peirano 2003). Atualmente, a antropologia argumenta em prol de uma definição etnográfica de ritual, apreendida pelo pesquisador em campo, junto à realidade observada. Cabe ao pesquisador desenvolver a capacidade de apreender o que os nativos estáo indicando como sendo único, excepcional, crítico e diferente (Peirano 2003: 09). Na esfera da Casa do Cantador, o que me era indicado como sendo especial era a Cantoria de Pé de Parede. Sendo assim, tomo as noites de cantoria como o rito por excelência da Casa do Cantador.

Pensar a Cantoria de Pé de Parede como um evento ritual é sublinhar alguns de seus traços fundamentais. A Cantoria exerce o papel de reunir e congregar pessoas. Além disso, o evento desvela algo sobre seus praticantes. É um momento em que imagens são construídas e comunicadas. Imagens que se referem às afirmaçóes da identidade nordestina, mas que também nos permite perceber que idéias sobre a tradição e o cantador estáo sendo reavaliadas e ganhando novas nuanças. $\mathrm{O}$ evento ritual é pensado enquanto uma forma de comunicação, expressando representaçóes sociais, edificaçóes de imagens, modos de inserção e afirmação do indivíduo no meio urbano. É o momento privilegiado para a exibição do modo de fazer a cantoria, do ser cantador e para a consolidação de uma nova imagem dessa manifestação cultural e de seus promotores.

Por ser um evento especial, a Cantoria de Pé de Parede é caracterizada por uma forma específica. Ela é também um ato performático. Analisar uma performance é voltar a atenção ao poder simbólico da comunicação humana. De acordo com Victor Turner (1982), a comunicação simbólica não se limita às palavras. Cada cultura usa seu repertório sensorial para transmitir mensagens. Assim, gesticulaçóes manuais, expressóes faciais, posturas corporais, respiraçóes, padróes de dança e movimentos sincronizados nos dizem muito sobre seus executores. O que o autor denomina "Antropologia da Performance" tem como objetivo trazer os dados/atos em sua plenitude, onde desejos e moçóes, estratégias pessoais e coletivas, situações de vulnerabilidade, cansaço e erros são levados em conta (op. cit.: 13). Náo pretendo trazer aqui essas idéias com o objetivo de empreender uma possível Antropologia da Performance. Os estudos de performance não são utilizados com o propósito de contribuir para uma discussáo teórica sobre o tema, mas apenas como um instrumento metodológico que possibilite ao pesquisador dar especial atençáo à dimensão gestual, cenográfica e comunicativa dos eventos rituais.

Dito isso, a Cantoria de Pé de Parede é um ato que envolve o estranhamento do cotidiano, ou seja, acontece em ocasióes especiais; pressupóe responsabilidade para com uma audiência, competência comunicativa, preparação, organização, expectativas, reaçóes da platéia e interaçóes (cf. Bauman 1986; Finnegan 1992; Langdon 1999). De que modo essas características fluem na dinâmica do evento aqui analisado?

As Cantorias de Pé de Parede são eventos em que se apresentam dois cantadores entoando versos de improviso. As noites de cantoria têm início por volta das vinte ou vinte e 
uma horas. Terminam quando os ouvintes se vão ou quando a dupla de cantadores se cansa. Normalmente, as cantorias não acontecem no anfiteatro da Casa, mas em um espaço improvisado próximo à cozinha. $\mathrm{O}$ local é preparado de modo especial. Existe um cuidado recorrente no que se refere à disposição das mesas e cadeiras no ambiente. As cadeiras reservadas aos cantadores ficam encostadas numa parede. As mesas destinadas ao público são distribuídas de modo que fiquem ao lado dos cantadores. A impressão que temos é a de que o cenário é organizado como se fosse um grande quadrado: num dos lados, os cantadores; no lado a sua frente, um espaço vazio; e nos dois lados restantes, a platéia.

A disposição espacial do cenário é arranjada para que os cantadores fiquem em evidência. Mesmo sem o recurso do palco, eles estão em destaque num dos cantos do saláo. $\mathrm{Na}$ frente dos cantadores não é colocada nenhuma mesa, o espaço fica vazio. $\mathrm{O}$ público evita a circulação pelo centro do saláo durante as apresentaçóes. Apesar do barulho das conversas, a atençáo da platéia está voltada aos cantadores. Porém, o cuidado maior com a organização da cena diz respeito apenas ao arranjo espacial das mesas e cadeiras de modo a evidenciar os cantadores no momento das apresentaçóes. Não existe uma atenção especial com a decoração do ambiente. Não notamos o uso de bandeiras, quadros e outros objetos que pudessem nos remeter à cantoria nordestina. Poucos ingredientes no cenário fazem referência à cantoria ou ao Nordeste.

No momento das apresentaçóes, os cantadores fazem uso de microfones para uma melhor recepção da voz. As cantorias são feitas ao som de violas ou violóes, cujas afinaçóes são bastante agudas e o acompanhamento musical é feito pelos próprios cantadores. $\mathrm{Na}$ Casa do Cantador, todos os cantadores aprenderam a tocar seus instrumentos de forma autodidata por meio da observação e da prática. Nenhum deles se considera músico. Segundo Dulce Lamas (1986), a relação entre melodia cantada e acompanhamento musical é relativa. $\mathrm{O}$ instrumento, executado pelo próprio cantador, destaca-se táo somente na introduçáo e nos pequenos interlúdios entre os cantadores (op. cit.: 38). O acompanhamento musical funciona como um acessório nas performances dos cantadores. O que é mais importante nas apresentaçóes é a voz do poeta e o cumprimento de determinadas regras do jogo, envolvendo habilidades específicas e o manejo de determinadas formas poéticas.

As formas poéticas utilizadas numa cantoria nordestina são várias. Os versos cantados são construídos na forma de diferentes estilos, gêneros ou modalidades. São alguns desses estilos: 1) sextilhas - um dos gêneros mais preferidos e usados pelos cantadores. Geralmente é utilizado no início das cantorias. São estrofes de seis versos (pés ou linhas) em que cada verso tem sete sílabas e as rimas ocorrem entre as linhas pares; 2) martelo agalopado - ritmo mais acelerado. Compóem-se de uma estrofe de dez versos em decassílabos, obedecendo a seguinte ordem de rima: abbaaccddc; 3) galope à beira mar - estrofe de dez versos, obedecendo à rima abbaaccbba. $\mathrm{O}$ último verso deve terminar com a frase "beira mar" ou "beira do mar"; 4) mote - estrofe de dez versos que pode ser de sete ou de dez sílabas. Entrega-se ao cantador o conjunto dos dois últimos versos que termina a estrofe de dez linhas. Além dessas modalidades aqui citadas foram catalogados por pesquisadores do assunto mais de setenta estilos de cantoria. Entre eles estão a gemedeira, os quadróes, martelo alagoano, Brasil Caboclo, rebatido, mourão, etc. (cf. Mota 1987; Seraine 1983; Ramos 1991).

As sextilhas, os martelos e os galopes fazem referência a uma série de temas. Falar sobre esses temas é mencionar o próprio caráter da cantoria. "Pois, trata-se de um tipo de música 
que se constitui na interação entre intérprete e ouvintes, em ocasióes específicas" (Travassos 1989: 116). As condiçóes do evento condicionam o conteúdo e o desenrolar da cantoria. De acordo com as reaçóes e respostas da platéia, os cantadores vão elaborando seus versos. Além de dominar a confecção de versos em diferentes modalidades ou estilos, os poetas precisam estar aptos para abordar qualquer tema que seja sugerido pelo público.

Os cantadores gostam de enfatizar que o "bom cantador" é aquele que canta temas atuais: assuntos políticos, econômicos e sociais do Brasil e do mundo. Segundo eles, os cantadores dos grandes centros urbanos não estão mais restritos aos "regionalismos", ou seja, não cantam apenas os aspectos da vida no sertão nordestino. Náo foram somente os cantadores que mudaram para as metrópoles brasileiras. $\mathrm{O}$ público que comparece às cantorias também é outro. Mesmo constituída principalmente por nordestinos, a platéia da Casa do Cantador não quer que os cantadores mencionem (unicamente) assuntos regionais. Assim, é muito usual a construção de versos sobre personagens da história do Brasil ou personalidades em voga no momento, como Sadam Hussen e Bin Laden. Os cantadores cantam também eventos atuais da política nacional, como o Programa Fome Zero e o caso Waldomiro Diniz.

No entanto, apesar dos cantadores destacarem que cantam principalmente assuntos da atualidade, os conteúdos de suas composiçóes são vários. As oposições entre o bem e o mal são freqüentes nos versos de improviso. A oposição ganha diferentes roupagens, podendo assumir a forma dos seguintes pares de oposição: Deus e o Diabo, o pobre e rico, o citadino e o matuto. Existem também versos dedicados aos assuntos religiosos. Quando os improvisos abordam tais temas, notamos a forte influência de uma moral cristã. Valores como o perdão e a caridade aparecem constantemente nas estrofes. Outro tema bastante comum é o próprio desafio entre os cantadores. O desafio é o momento dos cantadores estabelecerem abertamente uma peleja entre si, quando um pretende denegrir a imagem do outro por meio dos versos.

Além das formas poéticas citadas acima, os cantadores lançam mão de outros recursos em suas performances. Refiro-me às declamaçóes de poemas. Nas noites de cantoria existem momentos dedicados às poesias recitadas individualmente pelos poetas. A declamação é feita de uma forma especial. Os poemas são ditos/ cantados no mesmo ritmo das estrofes feitas de improviso, só que sem o uso de instrumentos musicais. Nesses momentos, apenas a voz do poeta ecoa pelo salão. A rima é pronunciada de modo cantado e bastante acentuada. Todas as poesias recitadas são de autoria de poetas populares nordestinos.

Nas apresentaçóes, seja recitando uma poesia ou fazendo um verso de improviso, os cantadores estão sujeitos aos erros: não conseguir fazer a rima, não pronunciar as palavras de forma segura, etc. Os acontecimentos são imprevisíveis. Mesmo assim, a utilização de pausas, silêncios, repetiçôes de palavras, não são recursos valorizados na performance. Essas eventualidades, quando acontecem, prejudicam a competência comunicativa do poeta frente a uma platéia em permanente estado de alerta.

Durante a performance, o público interfere por meio de palmas, risos e silêncio. A platéia avalia, discorda, corrige, aplaude e silencia de acordo com suas expectativas. O horizonte dessas expectativas abarca uma avaliação em que são consideradas: a rima dos versos; a velocidade com que o cantador elabora sua estrofe; a forma como o verso é cantado - visto que o cantador não pode gaguejar ou repetir palavras; a empatia e a identificação do público com o enredo da estrofe. A competência comunicativa do cantador depende de todo esse arcabouço de habilidades. 
Apesar das conversas, a platéia está atenta à performance. Nas noites de cantoria é interessante notar o quanto o público direciona sua atenção ao enunciado dos cantadores. Esta atençáo pode ser convertida numa tensão para o cantador, que a todo o momento se vê avaliado. $\mathrm{O}$ desempenho do poeta vai garantir a avaliação positiva ou negativa das pessoas que o assistem. $\mathrm{O}$ cantador que melhor comunica é aquele que tem rapidez na confecção das estrofes, que garante a continuidade temática dos versos e que pronuncia as palavras sem hesitação. Demonstro a questáo com um exemplo vivenciado por mim, em campo. Numa noite de cantoria, foi dado aos cantadores o seguinte mote: "Zumbi dos Palmares é símbolo da escravidão". O primeiro cantador apresentou a sua primeira estrofe da seguinte forma:

Vejo humilde escravizado

Todos os familiares

Sou Zumbi de Palmares

Para defender seu estado

Veja ele contentado

Que andou na contra-mão

Sofreu muito lá no chão

Passou fome, andou de pés

Zumbi dos Palmares é

Escravo da escravidáo.

Quando o primeiro cantador pronunciou o mote solicitado de forma errada, trocando "símbolo da escravidão" por "escravo da escravidáo", algumas pessoas da platéia repetiram o "mote certo" a fim de que o cantador pudesse se corrigir na próxima estrofe, e para que segundo cantador náo cometesse a mesma gafe. Mesmo assim, este emendou:

Eu quero seguir a esmo

Já botei no meu papel

Mas a Princesa Isabel

Que talvez seguiu a esmo
O negro é aquele mesmo

Que coloca o pé no chão

Se vive da escravidáo

Preto da cor de café

\section{Zumbi dos Palmares é \\ Escravo da escravidáo.}

O erro náo somente persistiu como o cantador fez uso de palavras repetidas e alguns versos parecem não fazer muito sentido. Pelo salão, algumas vaias puderam ser ouvidas. Na platéia, a agitação era grande: risadas e comentários jocosos denegrindo a imagem dos cantadores que náo conseguiam acertar o mote e nem fazer versos bem feitos.

A atenção do público, voltada ao enunciado dos cantadores, é garantida pelo uso de microfones que abafam as conversas e também pelas intervenções dialógicas feitas ao longo das performances. Os cantadores procuram estabelecer um diálogo com a platéia. O diálogo é estabelecido de diferentes formas. Uma delas acontece nos intervalos. Nesses momentos é fornecida uma série de explicaçóes sobre a cantoria nordestina. As explicações são dadas por alguém especial, o diretor da Casa do Cantador, que fica durante o rito como o principal responsável por essa tarefa. É ele também quem recebe os presentes, assumindo a função de cicerone do evento. Abaixo, fornecemos um exemplo:

Sejam bem-vindos! Toda a sexta-feira a gente tem um encontro daqueles que prestigiam a cantoria nordestina. Toda a sexta-feira a gente escala uma dupla. A dupla participa do início ao fim da cantoria (...). Muita gente não conhece as modalidades da cantoria. Sempre se começa com as sextilhas que é um verso feito em seis linhas. Agora, tem o galope à beira mar, tem o martelo agalopado, uma canção, um poema, um soneto... E quem souber pedir: "Quero que o cara fale sobre determinado assunto...”, os poetas estão aqui à mercê de vocês para qualquer assunto. 
Outras formas de diálogo com o público podem ser observadas ao longo de todo o evento. Ao recitar um poema nos intervalos da cantoria, o poeta procura chamar atenção do público, fazendo perguntas e dialogando abertamente com ele: "Vocês conhecem aquele poema? Não?! Então, eu vou recitar”. O auditório também pode ser usado como testemunha de uma situação de diálogo. Por exemplo, os poetas podem narrar uma piada como se tivessem vivenciado a situação. É como se o fato acontecesse com o próprio contador da história. A idéia é a de compartilhar um enredo não anônimo, propiciando certa autenticidade ao relato e ao mesmo tempo despertando o interesse do público.

Eu tava vindo agora lá do Nordeste e presenciei o acontecido. Vou contar... Tem alguém de menor aî́? [pergunta à platéia] Como tem muito cantador que ganha dinheiro, às vezes aparece até cantador gago. Ele não era diretamente um cantador. É que tinha um outro rapaz que um dia falou para ele: "Vamos comprar duas violas e sair cantando?”. O gago disse: “A... amos!”. Aí, compraram duas violas. Na primeira fazenda que chegaram, o fazendeiro disse: "É cantador? Eu gosto demais! Ave Maria! Gosto demais! Vamos fazer uma cantoria hoje à noite. Vou mandar matar o carneiro, ajeitar o 'tundum'...”. Como vocês sabem, tundum é o fígado do carneiro. O que aconteceu, entáo? À tarde, todo mundo foi jogar baralho. Caiu uma chuva daquelas e até molhou o baralho. Mais tarde, o dono da fazenda: "Epa, já tá cozido o tundum. Vamos comer? Mas antes vou pedir para os cantadores fazerem um refráo”. Aí, o cantador que não era gago disse ao gaguinho: "O que eu disser você repete. O verso vai ser o seguinte: À tarde choveu e molhou o baralho, e daqui a pouco eu como tundum". O gago cantou: "A...arde ô... ôveu e ô...olhou o a.... aralho e a...aqui a ...ouco eu ...como o ...um".
É importante destacar que o diálogo não é estabelecido somente durante os intervalos da cantoria, por ocasião da recitação de poesias ou da narração de piadas. O auditório pode se transformar no próprio assunto da conversa, ou melhor, das sextilhas. Numa dessas situaçóes a própria pesquisadora foi colocada no centro do debate:
Patrícia que é verdadeira
Veio aqui pra assistir
Ouvir repente bem feito
Pra depois que ela sair
Comunicar às colegas
Que faz gosto a gente ouvir

\section{Patrícia que veio ouvir \\ Para nos apreciar \\ Não é Patrícia França \\ Nem é Patrícia Pillar \\ Mas gosta de cantoria \\ Por isso veio escutar}

Segundo Paul Zumthor (1993), as intervenções dialógicas têm uma função pedagógica: é uma maneira de ensinar o momento e de advertir o público (:224). Na Casa do Cantador, elas são utilizadas como uma forma de chamar a atenção do público para o que está sendo enunciado pelos narradores. As intervençóes dialógicas são apenas uma das várias estratégias acionadas pelo cantador para garantir a sua competência comunicativa.

Uma das questóes mais interessantes nas apresentaçóes dos cantadores refere-se ao uso do corpo. O corpo não é um recurso muito utilizado nas performances. Durante todo o momento em que estão cantando, eles permanecem sentados, tocando suas violas. $\mathrm{O}$ corpo fica quase que imóvel nas cadeiras. Às vezes, quando uma estrofe faz referência a alguma pessoa da platéia, o cantador pode trocar olhares com o endereçado dos versos. Mas 
este recurso nem sempre é posto em prática. $\mathrm{O}$ cantador está concentrado nos versos construídos pelo poeta que está ao seu lado, formando a dupla. No entanto, eles também não se olham. O olhar está voltado para frente (lembrando que o cenário é organizado de modo que o espaço situado na frente dos cantadores esteja livre) e algumas vezes para o alto, sugerindo a busca por concentração e inspiração. A gestualidade expansiva náo se faz presente nas apresentaçóes. Porém, a "imobilidade" dos cantadores não é menos eficaz: ela direciona a dinâmica da performance à voz e às qualidades do poeta. "Os gestos - ainda que contidos - contribuem com a voz para fixar o sentido" (Zumthor 1993: 244).

Para Mário de Andrade (1984), a melodia da cantoria é algo fundamental nesta manifestação cultural. A monotonia da linha melódica facilita e torna mais clara a enunciação de textos em que importa muito o entendimento da palavra (op. cit.: 383). A melodia executada com poucas variaçóes (assim como a gestualidade "contida" dos cantadores) direciona a atenção do público para o que o cantador canta. A voz é o fator constitutivo da performance. Podemos ilustrar a questão com o momento da recitação. As poesias são decoradas e recitadas sem o auxílio de livros. Se o poeta ou o intérprete lê num livro o que os ouvintes escutam, a autoridade provém do livro, objeto visualmente percebido no centro do espetáculo. Quando o poeta canta ou recita, mesmo que o texto não seja improvisado e sim memorizado, sua voz lhe confere autoridade (Zumthor 1993: 19).

A voz é utilizada pelo cantador de modo particular e em proveito de uma possível avaliação positiva sobre o seu desempenho. As palavras são pronunciadas de forma estridente. As estrofes improvisadas são emitidas de modo claro e em alto volume quando a rima é acertada. Quando o poeta não consegue a rima, o som é feito de modo rápido quase imperceptível, só é possível distinguir auditivamente o som da vogal ou das vogais em que a rima terminaria. Tal estratégia é uma forma de proporcionar uma recepção auditiva semelhante ao que se esperava. Assim, a palavra falta, mas a intençáo da rima permanece.

A habilidade de fazer versos com rapidez, pronunciar as palavras sem hesitação e abordar temas que provoquem uma empatia com o público; a organização do cenário, que coloca o cantador no centro do espetáculo; as estratégias de utilização da voz; o andamento melódico da cantoria e a imobilidade gestual que direciona o foco da atenção para o poeta; são estratégias que garantem a competência comunicativa do cantador. A combinação desses e outros elementos, que veremos a seguir, possibilitam a eficácia do ritual.

\section{A “tradição" da Bandeja}

O público das Cantorias de Pé de Parede pode ser dividido em quatro categorias: 1) curiosos que pela primeira vez freqüentam a Casa. Normalmente, essas pessoas moram na Ceilândia, Taguatinga e imediaçooes, sendo em sua maioria nordestinas; 2) estudantes universitários que em grupos ou sozinhos sentam nas mesas com seus cadernos, anotando os versos dos cantadores; 3) cantadores que prestigiam a cantoria de seus colegas; 4) e, finalmente, os apologistas, nordestinos admiradores da cantoria e que contribuem com os cantadores, depositando na Bandeja notas ou cheques, cujos valores variam de vinte a cinqüenta reais.

Para assistir às cantorias não é obrigatório pagar ingresso ou couvert. Porém, o diretor da Casa carrega consigo um caderno, onde são feitas anotaçóes de temas solicitados pelo público aos cantadores, como também o registro dos presentes para que sejam convidados a "comparecer" no momento da Bandeja. Os presentes, convidados nominalmente pelo diretor, levantam-se 
e depositam o dinheiro numa bandeja de palha colocada ao lado dos cantadores. A Bandeja é explicada da seguinte forma para o público:

Quando a gente vai assistir a uma peça teatral, um filme, enfim, um show, a gente costuma sempre pagar na entrada. Aqui é ao contrário: não é na saída e nem na entrada, é no meio mesmo (...) Essa Bandeja é tradicional (...) Muita gente que não entende a cantoria nem o formato dela, chama a Bandeja de esmola, correr o chapéu. Não! Essa Bandeja é tradicional (...) A gente faz uma lista aqui (...) para ter mais praticidade (...). A gente sempre tem o Cristo, vamos dizer assim que começa (...) Eu vou chamar o Eron para batizar a Bandeja...

A explicação é uma das estratégias utilizadas pelos cantadores para valorizar uma manifestação cultural profundamente atrelada à idéia de subalternidade. A cantoria é uma manifestação pensada pelo senso comum e descrita por uma literatura especializada no assunto a partir da sua identificação com o meio rural e com setores subalternos da sociedade (cf. Andrade 1984; Barroso 1949; Campos 1973; Cascudo 2001; Maxado 1984; Mota 1987; Romero 1888). Para alguns desses autores, muitos cantadores utilizaram a cantoria como forma de renunciar à mendicância ou como uma possibilidade de abandonar os trabalhos na roça e sobreviver nos centros urbanos. No entanto, percebemos que a todo o momento, seja nas conversas ou na dinâmica dos eventos da Casa do Cantador, os cantadores procuram construir uma nova imagem da cantoria nordestina. $\mathrm{O}$ momento de explicação sobre a Bandeja é um exemplo dessa tentativa.

Os informantes evocam a idéia de tradição para tornar ímpar o momento da Bandeja. Para os cantadores, "correr o chapéu" é esmolar ou, na melhor das hipóteses, uma espécie de gorjeta. Diferente de uma simples gorjeta ou de uma esmola, a Bandeja é legitimada pela idéia de tradição. Não obstante, a "tradição" é pensada pelos informantes náo tanto a partir de sua relação com o passado, ou seja, como algo concretizado no tempo. A tradição não se situa na duração, e sim na obviedade. A tradição é usual e comum. É tudo aquilo que fazemos porque devemos fazer. A Bandeja é tradicional, assim como é tradicional comprar um ingresso para ver um filme no cinema; assim como é tradicional pagar a entrada de um show. A Bandeja não tem nada de infame ou vil: o pedido de dinheiro manifesta-se numa relaçáo entre iguais ${ }^{1}$.

Algumas questóes trazidas por Eric Hobsbawn (1997) podem ser úteis para pensarmos a maneira como a "tradição" da Bandeja é acionada nas Cantorias de Pé de Parede. Para o autor, a característica da tradição ${ }^{2}$ é a invariabilidade de um passado que impóe práticas fixas. Já o costume tem a dupla funçáo de motor e volante.

Os estudiosos dos movimentos camponeses sabem que quando numa aldeia se reivindicam terras ou direitos comuns "com base em costumes de tempos imemoriais" o que expressa não é um fato histórico, mas o equilíbrio de forças na luta constante da aldeia contra os senhores da terra ou contra outras aldeias (...). O "costume" não pode se dar ao luxo de ser invariável (...).

1. Um exemplo dessa questão pode ser visto na análise de Paul Zumthor (1993) sobre os pedidos de dinheiro feitos no momento do canto por trovadores medievais na Europa (: 63).

2. Pensada no sentido de tradição inventada: "um conjunto de práticas (...) de natureza ritual ou simbólica que visam inculcar certos valores e normas de comportamento através da repetição, o que implica (...) uma continuidade com o passado (...). Elas são reações a situaçóes novas que ou assumem a forma de referência a situações anteriores, ou estabelecem seu próprio passado através da repetição quase obrigatória” (Hobsbawn 1997: 09-10). 
O direito comum ou consuetudinário ainda exibe esta combinação de flexibilidade implícita e comprometimento formal com o passado. Nesse aspecto, a diferença entre "tradição" e "costume" fica bem clara. "Costume" é o que fazem os juízes; "tradição" (no caso, a tradição inventada) é a peruca (...) e outros acessórios e rituais que cercam a substância, que é a ação do magistrado (op. cit.: 10).

A Bandeja se refere ao que fazem os cantadores. Ela não é acionada como um acessório simbólico. O seu sentido não tem uma função simbólica precisa. O seu uso no ritual tem um objetivo prático. Com o tempo, o costume da Bandeja pode até ter sido transformado num aspecto formalizado das Cantorias de Pé de Parede. No entanto, sua função é técnica, prática e de direito: a Bandeja é um pagamento pelos serviços prestados pelos cantadores.

A indumentária utilizada pelos protagonistas do ritual também pode ser citada como mais uma estratégia de construção de outras imagens acerca da cantoria e de seus executores. Sendo identificados com o contexto de um Nordeste pastoril, poderíamos imaginar os cantadores usando em suas apresentaçóes roupas de couro e chapéu de vaqueiro. Mas, em todas as performances na Casa do Cantador, os cantadores trajam calças sociais, blusas de mangas compridas, cintos, sapatos engraxados e alguns capricham no perfume. Ivanildo Vila Nova, um dos mais respeitados cantadores da atualidade, numa entrevista ao Jornal do Brasil, comenta indignado e alinhado em paletó e camisa social: "você imagina que uma emissora de TV queria que a gente usasse chapéu de couro e peixeira?"3. Os cantadores residentes no Distrito Federal também se mostrariam indignados frente a tal

3. Entrevista dada à jornalista Helena Aragão (Jornal do Brasil), realizada em 19/06/04 e disponível em www. nordesteweb.com/not04_0604/ne_not20040618b. proposta. As transformaçóes ocorridas com a cantoria, principalmente quando seus praticantes atingiram os centros urbanos, implicou a apreensão de novos códigos típicos da modernização e identificados com os setores dominantes da sociedade nacional ${ }^{4}$. Os códigos dessa aparência não são aqueles do típico vaqueiro do sertáo nordestino, e sim de uma sociedade urbanizada e muito diferente da realidade rural. Apropriando-se de alguns desses códigos, os cantadores se vestem nas noites de cantoria e acionam a "tradição" da Bandeja.

A indumentária utilizada nas apresentaçóes e as explicaçóes para o momento da Bandeja refletem a maneira como os cantadores tentam se construir: eles são artistas. A autoconstrução do cantador-artista implica a elaboração de uma série de noçóes e o compartilhamento de códigos sociais. $\mathrm{O}$ cantador-artista precisa ter uma preocupaçáo excessiva com o uso correto da língua portuguesa e estar profundamente familiarizado com assuntos da atualidade política, econômica e social do país e do mundo. Pensar a cantoria enquanto arte é principalmente fazer menção a um determinado contexto: o urbano. Ao aproximar a cantoria da idéia de arte, os cantadores se afastam da vinculação ao ambiente rural. A formulação da noção de cantoria artística é uma forma de inserção numa nova realidade.

\section{Conterrâneos e comensalidade}

A Casa do Cantador pode ser pensada como uma forma de lazer, de entretenimento e de diversão no contexto urbano. No entanto, ela é principalmente um local de encontro, cujo motivo da reunião não é tanto o fato de que as pessoas ali presentes pertencerem ao mesmo

4. Eduardo Diatahy Menezes (1999) mostra essas transformaçôes e apreensôes de novos códigos nas narrativas populares de versos escritos, como a literatura de cordel. 
bairro, mas de estarem identificadas com um tipo de manifestação cultural, a cantoria nordestina.

A identificação com a cantoria nordestina leva à identificação com um espaço, o Nordeste. Conforme vimos, tal ligação não está expressa na decoração do ambiente. Eles não lançam mão de "objetos típicos" para compor o cenário das Noites de Cantoria. Os intérpretes não usam uma indumentária específica capaz de sugerir uma identificação com a regiáo. Mecanismos desse processo de identificação podem ser analisados a partir da idéia do conterrâneo, da comensalidade e dos conteúdos de algumas composiçôes dos cantadores.

Apesar de destacarem que náo cantam apenas assuntos regionais, os versos entoados pelos cantadores que abordam o Nordeste têm um grande espaço nas Cantorias de Pé de Parede. Nas estrofes, o Nordeste aparece de forma genérica, ou seja, é uma categoria homogeneizante. A categoria iguala os vários Estados que compóem a região. Antes de serem paraibanos, pernambucanos e cearenses, eles são nordestinos.

O Nordeste aparece também com a denominação de sertáo. Em grande parte dos versos, o Nordeste ou o Sertáo é extremamente valorizado. Os cantadores elaboram um rol das melhores coisas que existem por lá. A lista engloba desde pratos típicos e festas populares até o "caráter" do povo. A idéia é a de criar a imagem positiva de um lugar e de sua gente, e de diferenciá-lo das demais regióes do Brasil.

Os exemplos são inúmeros no que se referem à retomada de traços considerados típicos da regiáo. Os versos abaixo destacam a carne assada e o cuscuz. Tais pratos são tão valorizados no poema que a experiência de experimentá-los "propicia um encontro com seres divinos":

Nosso sertão tem sossego

Que eu quero sol e luz

Tem carne assada na brasa
Pra gente comer com cuscuz

Quem vai ao sertão e volta

Vê a cara de Jesus

(Casa do Cantador - Francisco Nunes, 21/11/03).

A valorização não é só de objetos considerados típicos da regiáo, mas também de seu povo. O tipo social do nordestino é construído a partir das seguintes qualidades: honestidade, força de vontade e capacidade de superar as adversidades:

O Nordeste não engana

Que se parece um porvir

Honesto pai de família

Vai o pão adquirir

A mulher pegando o braço

Pra ele também sorrir.

(Casa do Cantador - Elias Ferreira, 21/11/03).

A experiência dos migrantes na construção de Brasília também é relatada de modo que sublinhe as características positivas do povo nordestino. Nas comemoraçóes do aniversário de Brasília, realizadas na Casa do Cantador, um cantador improvisou:

Essa data não é feia

Que eu estou de cabeça erguida

Parabenizo Brasília

Por mais um ano de vida

Por suor de nordestino

Brasília foi construída.

(Casa do Cantador - Francisco Nunes, 21/04/04).

$\mathrm{Na}$ idealização e extrema valorização de coisas e de pessoas, a esperança da volta para o sertão é outra constante (pelo menos no momento ritual):

Eu estou feliz porque

Estou na localidade 
Mas do povo do Nordeste

Desse eu sinto saudade

De voltar para casa um dia

Eu tenho a maior vontade

(Casa do Cantador - Elias Ferreira, 21/11/03).

O sertão é de valor

É onde o povo me adora

Eu tenho a maior certeza

De quem só vive por fora

Pode não chorar com os outros

Mas chorar sozinho chora.

(Casa do Cantador - Chico Oliveira de Acopiara, 31/10/03).

Dentro do contexto da esperança da volta, do saudosismo e da valorizaçáo do Nordeste, para aqueles cantadores que aqui residem, cantando para o público da Casa do Cantador, Brasília assume uma função quase que utilitária. Seguindo o raciocínio dos poetas já citados anteriormente:

\section{Distante do pessoal}

Não sei se eu passei no teste

De tanto sofrer saudade

O meu compadre hoje investe

O dinheiro é em Brasília

E o sossego é no Nordeste.

(Casa do Cantador - Elias Ferreira, 21/11/03).

As apresentaçóes feitas na Casa do Cantador podem ser de cantadores que moram em Brasília ou daqueles que estão de passagem pela cidade. No entanto, todas as apresentaçóes na Casa do Cantador são de "cantadores do Nordeste". É feito um registro de todas as apresentaçóes realizadas na Casa, onde são anotados os nomes das duplas e as siglas dos estados de origem de cada cantador. No registro, cantadores que aqui residem durante vinte anos náo são catalogados pela sigla DF, mas sim pelas letras iniciais do estado em que nasceram. No início das apresentaçóes, o diretor da Casa sempre apresenta os cantadores, fazendo referência aos seus estados de origem e completando como uma espécie de anexo ou apêndice, o fato de viverem em Brasília.

Durante o rito, nas conversas com a platéia ou com os cantadores, o "morar em Brasília" soa como algo que parece não dizer muita coisa: "moro trinta anos aqui, mas sou de Recife", "sou de Pernambuco, apesar de morar quinze anos em Brasília”. Quando as pessoas chegam para a cantoria, são imediatamente indagadas a respeito da sua naturalidade, seja pelos cantadores ou pelo próprio público. A resposta à indagação é na maioria das vezes uma cidade nordestina, pelo menos essa é a resposta esperada por todos.

O ser de algum lugar do Nordeste assume um papel de destaque nas Noites de Cantoria. As pessoas fazem menção a essa questão nas conversas entrecortadas pelos sons das violas dos cantadores. A resposta dada à pergunta: “de onde você é?", é, sem dúvida, uma porta de entrada na Casa do Cantador.

Muitas pessoas são atraídas para a cantoria a fim de prestigiar e encontrar um conterrâneo cantador ou simplesmente para matar a saudade do Nordeste. E quando essa situação náo acontece, o espectador pode ser motivo de espanto. Foi o que aconteceu comigo numa de minhas primeiras visitas à Casa do Cantador. Reproduzo abaixo um trecho de meu diário de campo:

Após sair da Rodoviária do Plano Piloto às dezenove horas, em um ônibus lotado, chego para uma noite de cantoria por volta das vinte horas. Cumprimento algumas pessoas no portáo de entrada. Lá dentro, avisto o diretor da Casa, me aproximo e pergunto: "Lembra de mim?" Ele prontamente me responde: "Claro, você está fazendo uma pesquisa, né? Olha, se você quiser ficar um tempinho na biblioteca esperando 
a cantoria, eu abro pra você". Recuso, agradecida. Dou um giro pelas dependências. Leio a placa de inauguração e observo a escultura de um cantador esculpido em pedra. E assim permaneço... andando pela Casa. Um senhor que morava ali perto assistindo o DFTV [noticiário local] soube da cantoria, resolveu aparecer para conferir. Com muitas perguntas iniciou um diálogo comigo:

- Você gosta disso?

- Gosto, é legal.

- Será que tem que pagar alguma coisa?

- Não, acho que não.

- Onde você mora?

- No Plano Piloto.

- Você veio de carro?

- Vim de ônibus.

- Onde você nasceu?

- No interior do Rio.

- Mas, os seus pais são nordestinos, né?

- Não, eles são do Rio também.

Minha última resposta, o inquietou profundamente. O senhor aos gritos chamou sua esposa e filha, comentando perplexo: "Essa menina é doida. Vem lá do Plano só para assistir cantoria e nem é nordestina”. Sua surpresa não se referia tanto ao fato da "menina" ter vindo sozinha de noite e de ônibus para um lugar "táo longe", mas principalmente por ter feito tudo isso não sendo nordestina e nem ao menos tendo pais nordestinos.

Além das conversas e dos versos cantados que ressaltam a importância do "ser do Nordeste", está presente no ritual outro traço evocativo das "coisas de lá". O ser nordestino se expressa através do idioma da comensalidade. A culinária da Casa do Cantador é um fator de atração dos nordestinos residentes em Brasília e de curiosos.

Durante as cantorias, os presentes podem saborear pratos considerados típicos do Nordeste, como a carne de sol e a buchada de bode.
Para degustar a comida, os freqüentadores só precisam acionar um objeto bastante significativo: um sino de boi. Tocado o sino, você é prontamente atendido pela responsável por preparar os pratos ou por uma de suas ajudantes. É interessante perceber que nesta parte do ritual a utilização de um objeto que tem uma profunda ligação simbólica com o Nordeste pastoril é vista positivamente. O sino de boi é usado como um modo de divertir os convivas, que têm a possibilidade de fazer um pedido gastronômico de forma inusitada e particular. Diferentemente do uso de uma indumentária, capaz de aproximar os cantadores dos vaqueiros ou dos cangaceiros do sertáo, o sino de boi é convertido num ícone positivo, capaz de tornar o ambiente típico e diferente.

$\mathrm{Na}$ Casa do Cantador não existe a idéia de restaurante. $\mathrm{O}$ "serviço" não recebe um nome especial do tipo: "Bar", "Cantina" ou "Cantinho da...”. Os "fregueses" não comem em mesas previamente preparadas para uma refeição com saleiros, paliteiros, galheteiros e guardanapos. No "Bar", não é possível ver engradados ou copos sobre o balcão. $\mathrm{O}$ cardápio está resumido a uma cartolina, afixada numa parede, com as seguintes opçóes: buchada de bode, carne de sol, caldo de galinha, cerveja e refrigerante. Por um preço bastante acessível é possível saborear um farto "P.F." (prato feito). É o que muitos ouvintes e cantadores fazem por volta das vinte e duas ou vinte e três horas da noite.

O que pretendo enfatizar é a relação entre o que se faz e o que se come na Casa do Cantador. $\mathrm{O}$ ato de comer e cantar/ouvir estão imbricados na dinâmica do ritual. É como se você estivesse assistindo a cantoria e a comida fosse trazida a sua mesa. Tudo é feito num tom de informalidade, simplicidade e familiaridade. Muito mais que a noção de restaurante, a Casa cede espaço para a idéia de "cozinha". A cozinha é o ambiente familiar e aconchegante da casa, aqui com "C" maiúsculo. Vale 
destacar que esse espaço é dirigido por uma mulher. A cozinha na Casa do Cantador é o único espaço feminino num grupo eminentemente masculino.

A sedução dos pratos servidos na Casa do Cantador é a sensação de comer num ambiente descontraído e aconchegante. Uma sensação que se aproxima do "comer em casa". Outra imagem sedutora dos pratos é a da fartura. Não se privilegia a escolha de cerâmicas coloridas ou talheres lustrosos. Enfim, nada é chique, mas tudo é farto. A visualidade dos pratos servidos na forma de "P.F." é a de uma "montanha" interminável de comida. As imagens de fartura e da "casa" ajudam a estabelecer a idéia positiva do grupo. A suculenta buchada de bode, servida sem grandes ostentaçóes, mas com muita fartura e familiaridade, reforça a construção da boa imagem do grupo.

A comida é um tempero fundamental das relaçóes estabelecidas nas noites de cantoria. Comer num lugar público, por mais perto da casa que ele esteja, requer o conhecimento de um idioma cultural. Isso implica o como comer. Na Casa do Cantador, come-se em companhia de outras pessoas. A comensalidade é um veículo privilegiado para o estabelecimento de laços sociais.

"Encher a barriga ou encher a pança é um ato concreto destinado à saciedade do corpo, mas é também um modo de se referir a uma ação simbólica" (Da Matta 1994: 52). Em determinados eventos, a comida pode abrir uma brecha no mundo diário, engendrando ocasióes em que relaçóes sociais devem ser saboreadas e prazerosamente desfrutadas (op. cit.: 54). $\mathrm{Na}$ Casa do Cantador, fazer uma refeição não é um ato desprovido de uma ação simbólica. Não se come sozinho. O comer não é um ato individual e sugere tentativas de aproximaçóes entre as pessoas e o desfrute de relaçóes afetivas. Numa das noites na Casa do Cantador, um pouco antes da cantoria começar, fui surpreen- dida por um senhor que se prostrou na minha frente com um prato de comida. A Casa estava vazia, no saláo estavam apenas dois cantadores ocupados em arrumar a aparelhagem de som e o diretor que corria de um lado para outro, ajeitando os últimos preparativos para apresentação. O senhor, que eu já tinha visto algumas vezes na Casa, disse: "será que eu posso sentar com você?”. E logo em seguida se explicou: "É que eu não consigo jantar sozinho”. Sem esperar minha resposta, foi logo sentando e gritando para a responsável pela cozinha: "traz mais um prato aî". O senhor preferiu rachar o seu "P.F." com uma quase "estranha" a ter que se sentar numa mesa e comer sozinho.

Vários elementos que compóem uma noite de cantoria na Casa do Cantador nos permitem pensar as relaçóes das pessoas que ali estão com o Nordeste: a música; as letras das cançôes; as comidas que compóem o cardápio afixado numa das paredes do bar com carne de sol e buchada de bode; o sotaque das pessoas; frases do tipo: "vim porque sou baiano" ou as falas do diretor, momentos antes dar início às apresentações: "aqui é um espaço para reunir, uma referência para os nossos conterrâneos...”.

Rosani Rigamonte (1996) ao traçar alguns itinerários dos migrantes nordestinos na cidade de São Paulo, aponta o forró como uma via de acesso para mapear a presença cultural nordestina na capital. Segundo a autora, as festas de forró podem ser realizadas em lugares improvisados e pequenos, ou seja, são festas para encontrar amigos, para bater papo, divertirse entre conhecidos e conterrâneos. A autora aponta também para espaços cujos limites não estão restritos a uma rede local, como o caso do Centro de Tradiçóes Nordestinas (CTN), que reúne cerca de vinte mil pessoas nos finais de semana. Neste espaço, as pessoas, mesmo náo se conhecendo, se reconhecem enquanto partícipes de uma tradição e de uma trajetória comum (op. cit.: 251). 
Em seu estudo sobre a cantoria nordestina em São Paulo, Maria Ignez Ayalla (1988) afirma que a atualizaçáo da manifestaçáo em alguns bares no bairro do Brás permite o encontro entre conterrâneos e reforça a sua condição de manifestação artística regional, consolidando os vínculos com a cultura nordestina (: 94). $\mathrm{Na}$ capital federal, o reconhecimento de uma tradição (nordestina) é um dos motivos para as reunióes na Casa do Cantador. A "tradição" é reconhecida pelo sotaque, pela música, pela dança e pelas comidas típicas.

Nesses encontros se reúnem não apenas nordestinos no Distrito Federal, mas também não nordestinos que vivenciam os eventos, avaliam, elaboram e comprovam imagens referentes aos seus praticantes. As Cantorias de Pé de Parede realizadas pela Casa do Cantador são momentos privilegiados para a construção, afirmação e a possível comprovação de uma série de representaçóes. Além de imagens sobre o Nordeste, essas representações abarcam noções sobre a definição de uma manifestação cultural específica; sobre a idéia de cantador e a tentativa de construí-lo como um artista.

\section{Conclusão}

Ao mencionar que eu estava fazendo uma pesquisa sobre cantadores, muitas pessoas manifestavam reaçóes de desagravo: "poxa! Como você foi escolher esse tema? Repentista é muito chato!". Para essas pessoas, os repentistas eram aqueles que entoavam versos em troca de algum trocado, importunando turistas nas praias do Nordeste ou nos centros das grandes cidades. Nesse contexto, a cantoria nordestina é vista como uma manifestaçáo banal e muito próxima do ato de mendicância. Os cantadores são vistos como analfabetos e profundamente vinculados ao sertão nordestino. Bem, os cantadores que eu estudei procuram se construir de uma forma completamente contrária a essas versóes.
Diferente das imagens que colocam os cantadores como espécies de ambulantes que fazem suas apresentaçóes nas ruas, praças e praias, os cantadores nordestinos têm um local especial para as suas apresentaçóes, a Casa do Cantador. Diferente das praias, das ruas e dos bares, a Casa do Cantador é pensada como um centro cultural, um espaço construído para a valorização e atualização de uma dada manifestação cultural em Brasília, a cantoria nordestina.

$\mathrm{Na}$ percepção dos cantadores, a boa cantoria nordestina é aquela em que existe uma preocupação com o uso de um português considerado gramaticalmente correto (os bons cantadores não são mais analfabetos, têm "estudo"); o bom cantador é aquele que detém um arcabouço de informações sobre fatos importantes da humanidade no que se refere às esferas políticas, econômicas e sociais (não estão mais presos aos "regionalismos"). A própria indumentária utilizada nas apresentaçóes reflete a maneira como esses cantadores tentam se construir. Eles não querem ser identificados com o vaqueiro típico do sertão nordestino, mas com os códigos de uma sociedade urbanizada e com os valores da classe média. Para os cantadores a ameaça à preservação da cantoria parece ser a não "modernização" de seus promotores.

O cenário, o domínio de formas poéticas e de habilidades específicas, o conteúdo dos versos, a comensalidade, a vestimenta, a utilização da idéia de tradição são ingredientes que compóem as noites de Cantoria de Pé de Parede e que ajudam a formar o mote das mensagens comunicadas pelos cantadores durante a atualização da cantoria nordestina em Brasília. Analisar o manejo e a manipulação desses elementos nos remete às lutas pelo reconhecimento de imagens, representaçóes e processos identitários. Promovendo uma dada manifestação cultural, os cantadores objetivam a inserção em novos espaços e lutam pelo 
reconhecimento de um fazer entendido como artístico, técnico, aprimorado e moderno, reinventando a imagem da cantoria e conseqüentemente daqueles que a exercem.

\section{Cantoria de Pé de Parede: updating the Northeastern singing in Brasilia}

abstract Brasilia is a city whose population is formed by migrants. In its urban dynamics we observe groups, who revive and recreate culture manifestations, which are characteristic of their places of origin. This essay analyses one of these groups, cantadores nordestinos (Northeastern improvisers), and one event, Cantoria de Pé de Parede. While we describe the scenery where performance takes place, the particular poetic forms which are used, the importance of the idea of the fellow countryman and commensality, we also try to show some ways in which these popular poets build images of tradition, of poetic improvisation (cantoria), of Northeastern Region and of Brasilia.

keywords Northeastern improvisers. Performance. Tradition. Belonging to a community.

\section{Referências bibliográficas}

ANDRADE, Mario de. 1984. Os Cocos. Sáo Paulo: Duas Cidades; Brasília: INL, Fundação Pró-Memória.

ARAGÃO, Helena. 2004. "Notícias - Rap Repentistas". JB Online. Rio de Janeiro, 19 jun. 2004. Disponível em: <http://www.web3.com.br/not04_0604/ne_not_ 2004618b.htm>. Acesso em: 20 nov. de 2004.

AYALLA, Maria Ignez Novais. 1988. No arranco do grito: aspectos da cantoria nordestina. São Paulo: Ática.

BARROSO, Gustavo. 1949. Ao som da viola. Rio de Janeiro: Departamento de Imprensa Nacional.

BAUMAN, Richard. 1986. Story, performance, and event: contextual studies of oral narrative. Cambrigde: Cambrigde University Press.

CÂMARA CASCUDO, Luis. [1954]. Dicionário do Folclore Brasileiro. São Paulo: Global, 2001.

Da MATTA, Roberto. [1984]. O que faz o Brasil, Brasil? Rio de Janeiro: Rocco, 1994.
FINNEGAN, Ruth. 1992. Oral Traditions and Verbal Arts. New York: Routledge.

HOBSBAWN, Eric. [1983]. "Introdução: A Invenção das Tradiçōes”. In: E. Hobsbawn e T.Ranger (orgs.), A Invenção das Tradiçôes. São Paulo: Paz e Terra, pp. 9-23, 1997.

LAMAS, Dulce Martins. 1986. "A cantoria tradicional no nordeste brasileiro: suas características poéticomusicais". Revista Brasileira de Música, XVI: 30-41.

LANGDON, Ester Jean. 1999. "A Fixação da Narrativa: do mito para a poética de literatura oral". Horizontes Antropológicos, 5 (12): 13-36.

MAXADO, Franklin. 1984. O Cordel Televivo: futuro, presente e passado da literatura de cordel. Rio de Janeiro: CODECRI.

MENEZES, Eduardo Diatahy. 1999. "Das Classificaçôes por Ciclos Temáticos da Narrativa Popular em Verso: uma querela inútil”. Horizontes Antropológicos, n. 12: 279-294.

MORALES, Lúcia Arrais. 1993. A Feira de São Cristóvão: Um Estudo de Identidade Regional. Dissertação de Mestrado em Antropologia Social. Rio de Janeiro: PPGAS - UFRJ, datilo.

MOTA, Leonardo. [1921]. Cantadores. Belo Horizonte: Editora Itatiaia Limitada, 1987.

OSORIO, Patrícia Silva. 2005. Modernos e Rústicos: Tradição, Cantadores Nordestinos e Tradicionalistas Gaúchos em Brasilia. Tese de Doutorado em Antropologia Social. Brasília: PPGAS-UnB, datilo.

PEIRANO, Mariza. 2003. Rituais Ontem e Hoje. Rio de Janeiro: Zahar.

RAMOS, José Crispim. 1991. A Bahia e os Repentistas. Salvador: Escola Gráfica N. Senhora de Loreto.

RIBEIRO, Gustavo Lins. 1982. "Arqueologia de uma Cidade: Brasília e suas Cidades Satélites". Espaço e Debates: revista de estudos regionais e urbanos, 2 (6): 113-124.

RIGAMONTE, Rosani Cristina. 1996. "Severinos, Januárias e Raimundos: notas de uma pesquisa sobre migrantes nordestinos na cidade de São Paulo". In J. G. C. Magnani e L. L. Torres (orgs.), Na Metrópole: textos de antropologia urbana. São Paulo: Editora da Universidade de São Paulo; Fapesp.

ROMERO, Sylvio. 1888. Estudos sobre a Poesia Popular do Brazil. Rio de Janeiro: Laemmert \& Companhia.

SERAINE, Florival. [1968]. Antologia do Folclore Cearense. Fortaleza: Ed. UFC, 1983.

SOUSA, Nair Heloísa Bicalho de. 1983. Construtores de Brasilia: estudo de operários e sua participação política. Petrópolis: Vozes. 
TAMBIAH, Stanley Jeyaraja. 1985. Culture, Thought and Social Action: An Anthropological Perspective. London: Harvard University Press.

TRAVASSOS, Elizabeth. 1989. "Melodias para a improvisação poética no Nordeste: as toadas de sextilhas segundo a apreciação dos cantadores". Revista Brasileira de Música, XVIII: 115-129.

TURNER, Victor. 1982. From ritual to theatre: the buman seriousness of play. New York: Performing Arts Journal.

ZUMTHOR, Paul. [1987]. A Letra e a Voz: a "literatura" medieval. São Paulo: Companhia das Letras, 1993.

\section{Nota}

Este artigo é uma versão revisada e resumida do segundo capítulo de minha tese de doutoramento em Antropologia, intitulado "A Cantoria de Pé de Parede: o rito por excelência da Casa do Cantador". A tese - Modernos e Rústicos: Tradição, Cantadores Nordestinos e Tradicionalistas Gaúchos em Brasilia - foi defendida em 2005 no Departamento de Antropologia da Universidade de Brasília.

\section{autor Patrícia Silva Osório}

Doutora em Antropologia Social / UnB

Recebido em 15/02/2006

Aceito para publicação em 21/06/2006 